\title{
Herbal medicines supplied by community pharmacies in Lagos, Nigeria: pharmacists' knowledge
}

\author{
Kazeem A. OSHIKOYA, Ibrahim A. OREAGBA, Olayinka O. OGUNLEYE, Rashidat OLUWA, \\ Idowu O. SENBANJO, Sunday O. OLAYEMI. \\ Received (first version): 15-Sep-2013 Accepted: 9-Dec-2013
}

\begin{abstract}
${ }^{*}$
Background: The use of herbal medicines is on the increase globally and they are usually supplied in pharmacies as non-prescription medicines. Pharmacists are, therefore, responsible for educating and informing the consumers about rational use of herbal medicines.

Objectives: To evaluate the knowledge of pharmacists in Lagos, Nigeria with regards to the herbal medicines they supplied by their pharmacies. Methods: Pharmacists in charge of randomly selected 140 community pharmacies from 20 Local Government Areas in Lagos were required to fill out a self-administered questionnaire. We gathered information on their knowledge of the indications, adverse effects, potential drug-herb interactions and contraindications of the herbal medicines they supply in their pharmacies.

Results: Of the 140 questionnaires distributed, 103 (72.9\%) participants completed the questionnaire appropriately. The majority $(74 ; 71.8 \%)$ of the participants were males and $36-50$ years (56; $54.4 \%)$. The pharmacies supplied mostly Yoyo cleanser bitters $®(101 ; 98.5 \%)$, ginseng $(97$; $98.5 \%)$, Jobelyn $®(91 ; 88.3 \%)$, Ciklavit $₫(68$; $66.6 \%)$, gingko $(66 ; 64.1 \%)$, herbal tea $(66 ; 64.1 \%)$, and Aloe vera $(57 ; 55.3 \%)$. The pharmacists selfrated their knowledge of herbal medicines mostly as fair (39\%) and good (42\%), but they exhibited poor knowledge with regards to the indications, contraindications and safety profiles. Seventy participants consulted reference materials such as leaflet insert in the herbal medicines (56\%) and internet $(20 \%)$ before supplying herbal medicines. The information most frequently sought was herbdrug interactions $(85 \%)$, contraindications $(75 \%)$ and adverse effects (70\%).
\end{abstract}

\footnotetext{
"Kazeem Adeola OSHIKOYA. Department of Pharmacology, College of Medicine, Lagos State University. Lagos (Nigeria). kazeemoshikoya@ymail.com Ibrahim A. OREAGBA. Department of Pharmacology, College of Medicine, University of Lagos. Lagos (Nigeria). Olayinka O. OGUNLEYE. Department of Pharmacology, College of Medicine, Lagos State University. Lagos (Nigeria).

Rashidat OLUWA. Department of Pharmacology, College of Medicine, University of Lagos. Lagos (Nigeria). Idowu O. SENBANJO. Department of Paediatric and Child Health, College of Medicine, Lagos State University. Lagos (Nigeria).

Sunday O. OLAYEMI. Department of Pharmacology,

College of Medicine, University of Lagos. Lagos (Nigeria).
}

Conclusions: Community pharmacists need to be informed about the indications and safety profiles of herbal medicines.

Keywords: Phytotherapy; Herbal Medicine; HerbDrug Interactions; Pharmacies; Pharmacists; Health Knowledge, Attitudes, Practice; Nigeria

\section{PLANTAS MEDICINALES SUMINISTRADAS POR FARMACIAS COMUNITARIAS EN LAGOS, NIGERIA: CONOCIMIENTO DE LOS FARMACÉUTICOS}

\section{RESUMEN}

Antecedentes: El uso de plantas medicinales está en aumento en todo el mundo y son vendidas en farmacias comunitarias como medicamentos sin receta. Los farmacéuticos son, por tanto, responsables de educar e informar a los consumidores sobre el uso racional de las plantas medicinales.

Objetivos: Evaluar el conocimiento de los farmacéuticos de Lagos, Nigeria sobre las plantas medicinales suministradas en sus farmacias. Métodos: Se pidió a los farmacéuticos encargados de 140 farmacias comunitarias aleatoriamente seleccionadas en las 20 áreas de Gobiernos locales de Lagos que rellenasen un cuestionario autoadministrado. Recogimos información sobre su conocimiento de las indicaciones, efectos adversos, potenciales interacciones planta-medicamento y contraindicaciones de las plantas medicinales que suministraban en sus farmacias.

Resultados: De los 140 cuestionarios distribuidos, 103 participantes $(72,9 \%)$ lo completaron adecuadamente. La mayoría $(74 ; 71,8 \%)$ de los participantes eran hombres y tenían entre $36-50$ años $(56 ; 54,4 \%)$. Las farmacias suministraban en su mayoría Yoyo cleanser bitters ${ }^{\circledR}(101 ; 98,5 \%)$, ginseng $(97 ; 98,5 \%)$, Jobelyn $\AA(91 ; 88,3 \%)$, Ciklavit® $(68 ; 66,6 \%)$, gingko $(66 ; 64,1 \%)$, herbal tea $(66 ; 64,1 \%)$, and Aloe vera $(57 ; 55,3 \%)$. Los farmacéuticos auto-calificaron su conocimiento sobre plantas medicinales mayoritariamente como escaso $(39 \%)$ y bueno $(42 \%)$, pero demostraron poco conocimiento en relación a las indicaciones, contraindicaciones y perfiles de seguridad. 70 participantes consultaban materiales de referencia como los prospectos $(56 \%)$ e Internet $(20 \%)$ antes de suministrar una planta medicinal. La información vista más frecuentemente fueron las interacciones planta-medicamento $(85 \%)$, contraindicaciones $(75 \%)$ y efectos adversos $(70 \%)$. 
Conclusiones: Los farmacéuticos comunitarios necesitan más información sobre indicaciones y perfiles de seguridad de las plantas medicinales.

Palabras clave: Fitoterapia; Plantas medicinales; Interacciones de Planta-Medicamento; Farmacias; Farmacéuticos; Conocimientos, Actitudes y Práctica en Salud; Nigeria

\section{INTRODUCTION}

Herbal medicines have emerged as a common choice therapy for self-care among individuals who are now taking a more active role in their health care. ${ }^{1}$ In addition, irrational claims or advertisements by manufacturers, through different mass media, have enhanced the widespread use of herbal medicines among the general population in developing countries. ${ }^{2}$ According to the World Health Organization (WHO), herbal medicines are medications prepared from one or more herbs or plant parts (roots, stem bark, seeds and/or fruits). ${ }^{3}$ Many patients use a wide range of herbal medicines in addition to their conventional medicines. ${ }^{2,4}$ In Africa, herbal medicines are often used primarily to treat HIVIAIDs ${ }^{5}$, and sickle cell anaemia, asthma and epilepsy. ' Quite a number of the herbal medicines are not well researched and their formulation and sales are poorly regulated. They may be adulterated and potentially at risk for producing adverse effects and toxicity. ${ }^{2}$ Concomitant use of herbal and conventional medicines has resulted in a coagulation problem manifesting as postoperative bleeding. ${ }^{6}$ Adulteration of an herbal medicine with diazepam was responsible for sedation of a pre-operative patient in India. ${ }^{7}$ It also has been documented in the literature that pre-operative use of herbal medicines was responsible for a prolonged or inadequate anaesthesia in surgical patients. ${ }^{7}$

Globally, community pharmacists are a major supplier of complementary herbal medicines. They, therefore, have an important role to play in the use of herbal medicines procured by their customers since the products are sold mostly as over-thecounter (OTC) medicines in many countries. ${ }^{8}$ In addition, patients often seek advice and information on medicines, including herbal medicines, from pharmacists.

Previous studies from Nigeria, Kuwait, United Arab Emirates, Oman, and Australia have shown that most community pharmacists did not possess adequate knowledge of potential interaction profiles and side effects of the herbal medicines they supplied. $^{9-13}$ There is also evidence to suggest that the knowledge of community pharmacists is inadequate with regards to counselling patients on herbal medicines. ${ }^{14}$ Herbal medicines are integral part of complementary medicines (CMs). ${ }^{15}$ Studies in Australia, the United Kingdom, the United States of America and Singapore have all indicated that pharmacists rate their knowledge and ability to counsel consumers on CMs as inadequate. ${ }^{13,16-19}$ Many factors are responsible for this lack of knowledge. Among the factors is non- mandatory implementation of $\mathrm{CM}$ teaching into pharmacy courses and variation in the extent to which it is thought. $^{20,21} \mathrm{~A}$ high positive correlation between educational exposure and perceived usefulness of CMs has been documented in the literature. ${ }^{22}$ Despite varied teaching, there is a strong interest in learning more about CMs by both undergraduate pharmacy and medical students. ${ }^{22-24}$ Other compounding factors include lack of accurate and easily accessible information, including good patient resources. ${ }^{14}$ Pharmacists are interested in integrated non-biased and evidence-based information about herbal medicines ${ }^{14,25}$, but available resources may not be accurate to provide this information. Studies have indicated leaflet or package insert of herbal medicines, undergraduate pharmacognosy lecture notes, textbooks, magazine, drug sales representatives, and internet as the likely sources of information about herbal medicines for community pharmacists. ${ }^{9-13}$

The National Agency for Food and Drug Administration and Control (NAFDAC) Act 1993, as amended in 2005, prohibits the manufacture, importation, exportation, distribution, advertisement or sale of any herbal medicine or related product unless it is appropriately labelled and registered as required by the agency. ${ }^{26}$ The regulation stipulates that herbal medicines and related products labelling should be informative and accurate, not promotional in tone, not misleading or provide a false claim. The agency requires that adequate information about an herbal medicine should appear on its package insert. These include description of the product; description of its clinical pharmacology, indications and usage, contraindications, warnings against misuse, precautions, dosage and administration, adverse reactions, abuse and dependence, symptoms of over dosage and antidote; description of how it is supplied. The labelling should also describe the animal pharmacology, toxicology, clinical studies, storage conditions, and references of the herbal medicines.

Despite the detailed information required by NAFDAC on herbal medicine package inserts, most pharmacists in Nigeria remained inadequately prepared academically to meet the information needs of patients on herbal medicines since they were not formally taught this topic in schools of pharmacy. ${ }^{9}$ In order to give advice to patients, pharmacists must be knowledgeable about the indications, dosing, adverse effects, toxicity, and potential interactions of herbal medicines with conventional medicines. The present study, therefore, aimed to evaluate the knowledge of community pharmacists in Lagos, Nigeria, about the herbal medicines they supply in their pharmacies.

\section{METHODS}

The study was conducted between $1^{\text {st }}$ January and $31^{\text {st }}$ March, 2012. Community pharmacies were selected from a list of Association of Community Pharmacists of Nigeria (ACPN) in Lagos State available as at $31^{\text {st }}$ December, 2011. Of the 540 community pharmacies with valid ACPN licence in 2011 , only 220 had renewed their licence for the 
year 2012. All the licensed community pharmacies are operated by pharmacists who were registered and licensed by the Pharmacists Council of Nigeria (PCN).

Inclusion criteria include registered community pharmacies with a valid 2012 ACPN licence, and community pharmacies with a pharmacist in attendance for at least 8 hours daily. Rural community pharmacies were excluded because they were often run by a pharmacy technician.

Among the community pharmacies with a valid 2012 ACPN licence, 140 were randomly selected from 20 Local Government Areas (LGAs). Firstly, the location of the pharmacies was stratified into 20 LGAs in order to cover the whole of Lagos State. Secondly, because the pharmacies were not evenly distributed across the LGAs, we randomly selected a total of 7 pharmacies from each LGA. Pharmacies with branches or other outlets were counted as one and only one of its outlets was selected for the study. In cases where more than one pharmacist was available in the pharmacy only one was allowed to participate in the study.

\section{Sample size determination}

Raosoft $\circledast$ sample size calculator was used to determine the sample size. ${ }^{27}$ A sample size of 140 was calculated from the 220 community pharmacies with valid 2012 ACPN licence during the study period using $5 \%$ error margin at $95 \%$ confidence interval, assuming $50 \%$ of the participants responded.

\section{Study design and data collection}

Data collection was carried out using a structured self-administered questionnaire, purposely designed for this study (See: online supplementary material). The questionnaire was developed from the previous studies that explored herbal medicine knowledge of community pharmacists in Nigeria and other developing as well as developed countries. ${ }^{9-19}$ The questions were mainly close-ended or multiplechoice with some open-ended.

The questionnaire was designed to obtain demographic data including age, gender, year of qualification, and years of practice of the community pharmacist. It also sought the relevant information on the types of herbal medicine they supply in the pharmacy and their indications. Participants were required to select the herbal medicines from a predetermined list, and also to suggest others that were not included on the list. They also were required to list the indications for the herbal medicines. Other sections of the questionnaire sought the knowledge base of the community pharmacists on the uses, contraindications and potential drug-herb interaction; and relevant training received on the use of herbal medicines. They also were required to rate their knowledge on a 5-point Likert scale (always, regularly, occasionally, rarely, or never). Information was also sought about the participants' perceived professional responsibilities towards herbal medicines use by their customers.

In this study, we differentiated herbal medicines from mega-dose vitamins and minerals by defining herbal medicines as a refined or raw extract from a plant origin. Based on this definition, multivitamin and mineral supplements were excluded as herbal medicines. Included in the herbal medicine lists are multivitamin or mineral supplements containing herbs (Gingko biloba and ginseng of any origin), and any medicinal products containing refined or raw plant parts (leaf, stem, root, fruit, or seed).

The questionnaires were given (person-to-person) to the selected participants to be filled in their respective pharmacies without consulting any reference material. The name of the pharmacy or pharmacist was not requested on the questionnaire to ensure anonymity of the participants. The pharmacists were informed that their responses would help in determining whether there was an adequate training or there was a need for an additional training for pharmacists in the area of herbal medicines. The pharmacists were also informed that willingness to participate in the study was taken as consent.

The questionnaires were pre-tested among five experienced registered community pharmacists in the LGAs that were not included in the study. Responses obtained were used to modify the predetermined list of herbal medicines and knowledge of the pharmacists.

\section{Ethical considerations}

The study was approved by the ethics committee of the Pharmacist Council of Nigeria.

\section{Data analysis}

Statistical analysis of the results was performed using the Statistical Package for the Social Sciences (SPSS), version 16. The data on demographics, the types of herbal medicines supplied by the community pharmacies as well as the pharmacists' knowledge of herbal medicines, were analysed using simple descriptive statistics. Comparisons between the gender (male or female), age ( $\leq 40$ or $>40$ years), duration of qualification ( $\leq 10$ or $>10$ years) or duration of practice ( $\leq 10$ or $>10$ years) of the pharmacists and their self-rated general knowledge of herbal medicines or self-rated knowledge of specific herbal medicines was made using the Pearson Chi-squared test at $5 \%$ level of significance.

\begin{tabular}{|c|c|}
\hline Parameters & Frequency \\
\hline \multicolumn{2}{|l|}{ Gender } \\
\hline Male & $74(71.8 \%)$ \\
\hline Female & $29(28.2 \%)$ \\
\hline \multicolumn{2}{|l|}{ Age (years) } \\
\hline $20-35$ & $24(23.3 \%)$ \\
\hline $36-50$ & $56(54.4 \%)$ \\
\hline $51-65$ & $18(17.5 \%)$ \\
\hline Over 65 & $5(4.8 \%)$ \\
\hline $\begin{array}{l}\text { Median year of qualification } \\
\text { (range) }\end{array}$ & $13(2-42)$ \\
\hline $\begin{array}{l}\text { Median duration of practice in } \\
\text { years (range) }\end{array}$ & $10(1-35)$ \\
\hline \multicolumn{2}{|l|}{ Additional qualification } \\
\hline None & $87(84.5 \%)$ \\
\hline Fellowship & $8(7.8 \%)$ \\
\hline Master degree & $5(4.8 \%)$ \\
\hline Diploma & $2(1.9 \%)$ \\
\hline Doctorate degree & $1(1.0 \%)$ \\
\hline
\end{tabular}




\begin{tabular}{|c|c|c|}
\hline $\begin{array}{l}\text { Herbal remedy } \\
\text { (Latin names of the components) }\end{array}$ & Main indication(s) $)^{\star *}$ & $\begin{array}{l}\text { Number of } \\
\text { pharmacies } \\
(\%)\end{array}$ \\
\hline $\begin{array}{l}\text { Yoyo Cleanser bitters } \AA \\
\text { (Aloe vera, Acinus avensis, Chenopodium murale, } \\
\text { Citrus aurantofolia, Cinamomum aromaticum) }\end{array}$ & $\begin{array}{l}\text { Improves digestion, boosts immune system, prevents } \\
\text { chronic fatigue }\end{array}$ & $101(98.5)$ \\
\hline $\begin{array}{l}\text { Ginseng } \\
\text { (Panax ginseng) }\end{array}$ & $\begin{array}{l}\text { Provides energy and prevents fatigue, improves } \\
\text { cognitive function, for treating inflammation, cancer } \\
\text { prevention, and for treating erectile dysfunction }\end{array}$ & $97(93.2)$ \\
\hline $\begin{array}{l}\text { Jobelyn } \AA \\
\text { (Sorghum bicolour Moench leaves, Parquetina } \\
\text { nigrescens, Harungana } \quad \text { madagascariensis, } \\
\text { Anacardium occidentale, Waltheria indica) }\end{array}$ & $\begin{array}{l}\text { Treatment and prevention of stroke, increases CD4 } \\
\text { count in HIV infected patients, boosts blood cells, } \\
\text { improves the general well-being of a patient, and for } \\
\text { treating arthritis }\end{array}$ & $91(88.3)$ \\
\hline $\begin{array}{l}\text { Ciklavit } \circledast \\
\text { (Cajanus cajan) }\end{array}$ & $\begin{array}{c}\text { Use in the effective management of pain crisis in sickle } \\
\text { cell disease }\end{array}$ & $68(66.6)$ \\
\hline $\begin{array}{l}\text { Ginkgo } \\
\text { (Ginkgo biloba) }\end{array}$ & $\begin{array}{l}\text { For treating memory disorders (Alzheimer's disease), } \\
\text { disorders related to reduced blood flow in the brain, } \\
\text { especially in older people, difficulty in concentrating, } \\
\text { mood disturbances, and hearing disorders. Also use } \\
\text { for treating problems related to poor blood flow in the } \\
\text { body, including leg pain when walking (claudication), } \\
\text { and Raynaud's syndrome (a painful response to cold, } \\
\text { especially in the fingers and toes). }\end{array}$ & $66(64.1)$ \\
\hline $\begin{array}{l}\text { Herbal tea } \\
\text { (Cassia senna, Cassia angustifolia, Sennae folium) }\end{array}$ & $\begin{array}{l}\text { Use to calm and relax the mind, prevention of heart } \\
\text { diseases, promotes digestion, promotes wellness, } \\
\text { boosts the immune system, and prevents cold. }\end{array}$ & $66(64.1)$ \\
\hline $\begin{array}{l}\text { Aloe vera } \\
\text { (Aloe barbadensis) }\end{array}$ & $\begin{array}{l}\text { Oral Aloe gel is used for treating osteoarthritis, bowel } \\
\text { diseases including ulcerative colitis, fever, itching and } \\
\text { inflammation, and to increase blood level. It is also } \\
\text { used for gastric ulcers, diabetes, asthma, and for } \\
\text { treating some side effects of radiation treatment. } \\
\text { Topical aloe gel for skin conditions including burns, } \\
\text { sunburn, frostbite, psoriasis, and cold sores. Others } \\
\text { uses include surgical wounds and bedsores. }\end{array}$ & $57(55.3)$ \\
\hline $\begin{array}{l}\text { Yemkem } ® \text { products (FJK flusher) } \\
\text { (Cassia alata, Citrus medica var. acida, Aloe barbaris, } \\
\text { Aloe vera, Cassia augustifolia vahl, Cassia siamea, } \\
\text { Khaya senegalensis, Xylopia aethiopica, Gongronema } \\
\text { latifolium, Khaya grandifolia, Moringa lucida, } \\
\text { Anthocleista djalonensis, Citrullus var. lanatus) }\end{array}$ & $\begin{array}{l}\text { Supports virtually every function in the body including; } \\
\text { vision, liver, kidney, heart, cardiovascular and healthy } \\
\text { hair and nails. Use for energizing the body } \\
\text { metabolism, boosts the immune system. }\end{array}$ & $31(30.1)$ \\
\hline $\begin{array}{l}\text { GNLD® products (herbal rest and relax) } \\
\text { (Hypericum perforatum, Passiflora incarnata, Verbena } \\
\text { officinalis, Matricaria recutita, Schisandra chinensis, } \\
\text { Scutellaria lateriflora } \\
\text { Melissa officinalis, Turnera diffusa) }\end{array}$ & $\begin{array}{c}\text { Relaxes the body system and/or a promotes good } \\
\text { night sleep }\end{array}$ & $23(22.3)$ \\
\hline $\begin{array}{l}\text { Forever living products } ® \text { (Forever lite) } \\
\text { Soybean oils, brewer's yeast, guar gum, beta } \\
\text { carotene, tocopherol, soy lecithin, chromium yeast, } \\
\text { spirulina (Arthrospira platensis and Arthrospira } \\
\text { maxima) }\end{array}$ & Promotes healthy living and age re-new & $21(20.4)$ \\
\hline $\begin{array}{l}\text { Alomo bitter }{ }^{\circledR} \\
\text { African breadfruit (Treculia africana Decne. Ex Trécul), } \\
\text { stem bark of African mahogany (Khaya ivorensis A. } \\
\text { Chev.) }\end{array}$ & $\begin{array}{c}\text { Prevents high blood sugar level, cleanses the body } \\
\text { systems, and increases libido }\end{array}$ & $18(17.5)$ \\
\hline $\begin{array}{l}\text { Tianshi® product (Capsilite) } \\
\text { Capsaicin extract, anhydrous caffeine, black pepper } \\
\text { extract, nicotinamide (vitamin } B_{3} \text { ) }\end{array}$ & $\begin{array}{l}\text { helps burn fat and inhibits the growth of fat cells, } \\
\text { accelerates calorie burning } \\
\text { stimulates the oxidation of fats and carbohydrates, } \\
\text { reduces appetite, and improves performance and } \\
\text { endurance }\end{array}$ & $16(15.5)$ \\
\hline $\begin{array}{l}\text { Echinacea } \\
\text { (Echinacea angustifolia) }\end{array}$ & $\begin{array}{l}\text { Used primarily to treat or prevent cold. It is also used } \\
\text { against many other infections including urinary tract } \\
\text { infections, vaginal candidiasis, genital herpes, sepsis, } \\
\text { and tonsillitis. }\end{array}$ & $10(9.7)$ \\
\hline $\begin{array}{l}\text { Oroki herbal mixture }{ }^{\circledR} \\
\text { Stem bark of African mahogany (Khaya ivorensis } \\
\text { A.Chev.) tree, pattern wood (Alstonia congensis } \\
\text { Engl.), mango (Mangifera indica L.) leaves, Sorghum } \\
\text { (Sorghum bicolour Moench) }\end{array}$ & $\begin{array}{c}\text { It is traditionally used for pile, dysentery, constipation, } \\
\text { fibroid, diarrhoea, bloody stool, abdominal and waist } \\
\text { pain, and haemorrhoid. }\end{array}$ & $9(8.7)$ \\
\hline $\begin{array}{l}\text { St John's wort } \\
\text { (Hypericum perforatum L.) }\end{array}$ & $\begin{array}{l}\text { Improves mood, and decreases anxiety and insomnia } \\
\text { related to depression. }\end{array}$ & $6(5.8)$ \\
\hline $\begin{array}{l}\text { Valerian } \\
\text { (Valeriana officinalis L.) }\end{array}$ & $\begin{array}{l}\text { Valerian seems to improve the sleep quality of people } \\
\text { who are withdrawing from the use of sleeping pills }\end{array}$ & $6(5.8)$ \\
\hline
\end{tabular}




\begin{tabular}{|c|c|c|}
\hline $\begin{array}{l}\text { Ajase poki-poki® } \\
\text { Tobacco (Nicotiana L.) leaves, stem bark of coconut } \\
\text { (Cocos nucifera L.), seeds and coat of alligator pepper } \\
\text { (Aframomum melegueta K.Schum.) }\end{array}$ & $\begin{array}{l}\text { Used to treat diarrhoea, abdominal upset, dysentery, } \\
\text { pile, constipation, decreased libido and weak erection. }\end{array}$ & $4(3.9)$ \\
\hline
\end{tabular}

\section{RESULTS}

All the 140 questionnaires distributed were responded to but only $103(73.6 \%)$ were completed appropriately. The 103 questionnaires were those analysed in this study. The demographics of the respondents are presented in Table 1. More males than females appropriately responded to the questionnaires. Majority of the pharmacist had no additional qualification.

Table 2 shows the types, composition, indications, and frequency distribution of the pharmacies that supplied the herbal medicines. The pharmacies supplied mostly Yoyo cleanser bitters ${ }^{\circledR}(101$; $98.5 \%)$, ginseng $(97 ; 98.5 \%)$, Jobelyn $®(91 ; 88.3 \%)$, Ciklavit $\circledast(68 ; 66.6 \%)$, gingko $(66 ; 64.1 \%)$, herbal tea $(66 ; 64.1 \%)$, and Aloe vera $(57 ; 55.3 \%)$.

It was self-reported by the pharmacists that more males $(57 ; 53.3 \%)$ than females $(46 ; 44.7 \%)$ purchased the herbal medicines. The herbal medicines were purchased for the use of middleaged adults $(61 ; 59.2 \%)$, elderly $(29 ; 28.8 \%)$ and children (13; 10.0\%).

The pharmacists rated their knowledge of herbal medicines as excellent (4\%), very good $(9 \%)$, fair $(39 \%)$, and good $(42 \%)$. They also were of the opinion that herbal medicines may be effective (39; $37.9 \%)$, fairly effective $(19 ; 18.4 \%)$, or very effective $(14 ; 13.6 \%)$. Although, all the herbal medicines supplied by the pharmacies were approved by the NAFDAC, yet the majority of the pharmacists $(71$; $68.9 \%)$ were uncertain about their safety. However, $19(18.4 \%)$ considered them to be harmless, while $13(12.4 \%)$ believed that they may be harmful.

The self-rated knowledge of the community pharmacists with regards to the uses and potential adverse effects of some of the herbal medicines is presented in Table 3. Most of the respondents were in agreement with the general questions on herbal medicines. However, the respondents either generally disagree or uncertain about the answers to the questions on specific herbal medicines.

There was no significant association between the gender of the pharmacists and their self-rated general knowledge of herbal medicines $(P=0.182)$ or self-rated knowledge of specific herbal medicines $(P=0.091)$ they supplied. Pharmacists older than 40 years appeared to self-rate their general knowledge of herbal medicines higher than those who were 40 years and below $(P=0.021)$. However, there was no significant difference in their self-rated knowledge of the specific herbal medicines $(P=0.262)$. In contrast, pharmacists who qualified over 10 years self-rated their general knowledge of herbal medicines $(P=0.012)$ and knowledge of specific herbal medicines $(P<0.01)$ higher than those who qualified 10 years and below. Similarly, pharmacists who have practiced for 10 years and above self-rated their general knowledge of herbal medicines $(P<0.01)$ and knowledge of specific herbal medicines $(P<0.01)$ higher than those who have practiced for 10 years and below.

Table 4 shows the information sought by the community pharmacists from the buyers of herbal medicines. Although herbal medicines are sold at the pharmacies as over the counter medicine (OTC), yet over half of the pharmacists always or regularly enquired about who prescribed the herbal medicines before they were supplied. Similarly, over half of the respondents always or regularly counselled the users about the administration and potential adverse effects of the herbal medicines supplied. Many of the pharmacists occasionally, rarely or never took the medical or medication history of the potential herbal medicine users. Similar trend was observed with consulting

\begin{tabular}{|c|c|c|c|c|c|}
\hline Question & Strongly agree & Agree & Uncertain & Disagree & Strongly disagree \\
\hline $\begin{array}{l}\text { Herb-herb interaction may occur with herbal } \\
\text { medicine use }\end{array}$ & $43(41.7 \%)$ & $43(41.7 \%)$ & $15(14.6 \%)$ & $2(1.9 \%)$ & - \\
\hline $\begin{array}{l}\text { Herb-drug interaction may occur when herbal } \\
\text { medicine is used with a conventional medicine }\end{array}$ & $55(53.4 \%)$ & $38(36.9 \%)$ & $9(8.7 \%)$ & $1(1.0 \%)$ & - \\
\hline $\begin{array}{l}\text { Herbal medicine may be contraindicated in } \\
\text { pregnancy }\end{array}$ & $60(58.3 \%)$ & $31(30.1 \%)$ & $10(9.7 \%)$ & $1(1.0 \%)$ & $1(1.0 \%)$ \\
\hline Yoyo cleanser bitters $₫$ is an immune booster & $7(6.8 \%)$ & $12(11.6 \%)$ & $52(50.5 \%)$ & $27(26.2 \%)$ & $5(4.9 \%)$ \\
\hline $\begin{array}{l}\text { Ginseng may increase blood pressure at normal } \\
\text { dose }\end{array}$ & $9(8.7 \%)$ & $22(21.4 \%)$ & $50(48.5 \%)$ & $18(17.5 \%)$ & $4(3.9 \%)$ \\
\hline Ginseng is contraindicated in diabetes mellitus & $3(2.9 \%)$ & $12(11.6 \%)$ & $59(57.3 \%)$ & $23(22.3 \%)$ & $6(5.8 \%)$ \\
\hline $\begin{array}{l}\text { St John's wort is used for controlling mild to } \\
\text { moderate hypertension }\end{array}$ & $6(5.8 \%)$ & $10(9.7 \%)$ & $81(78.6 \%)$ & $3(2.9 \%)$ & $3(2.9 \%)$ \\
\hline St John's wort may increase digoxin blood level & $4(3.9 \%)$ & $9(8.7 \%)$ & $85(82.5 \%)$ & $3(2.9 \%)$ & $2(1.9 \%)$ \\
\hline Ginkgo may delay onset of dementia & - & $1(1.0 \%)$ & $62(60.2 \%)$ & $22(21.4 \%)$ & $18(17.5 \%)$ \\
\hline $\begin{array}{l}\text { Ginkgo may increase the risk of bleeding when } \\
\text { used concurrently with warfarin }\end{array}$ & $13(12.6 \%)$ & $22(21.4 \%)$ & $61(59.2 \%)$ & $5(4.9 \%)$ & $2(1$ \\
\hline $\begin{array}{l}\text { Valerian should be used with caution in a patient } \\
\text { on benzodiazepines }\end{array}$ & - & $9(8.7 \%)$ & $84(81.6 \%)$ & $8(7.8 \%)$ & $2(1.9 \%)$ \\
\hline
\end{tabular}




\begin{tabular}{|l|c|c|c|c|c|}
\hline \multicolumn{1}{|c|}{ Question } & Always & Regularly & Occasionally & Rarely & Never \\
\hline $\begin{array}{l}\text { Pharmacists enquired about herbal medicine } \\
\text { prescriber }\end{array}$ & $22(21.4 \%)$ & $31(30.1 \%)$ & $28(27.2 \%)$ & $19(18.4 \%)$ & $3(2.9 \%)$ \\
\hline Medical history taken from the buyers & $18(17.5 \%)$ & $29(28.2 \%)$ & $36(35.0 \%)$ & $15(14.6 \%)$ & $5(4.9 \%)$ \\
\hline Medication history taken from the buyers & $17(16.5 \%)$ & $27(26.2 \%)$ & $38(36.9 \%)$ & $16(15.5 \%)$ & $5(4.9 \%)$ \\
\hline $\begin{array}{l}\text { Consult referenced materials before supplying } \\
\text { herbal medicines }\end{array}$ & $13(12.6 \%)$ & $16(15.5 \%)$ & $41(39.8 \%)$ & $22(21.4 \%)$ & $11(10.7 \%)$ \\
\hline $\begin{array}{l}\text { Counsel buyers about administration of the } \\
\text { herbal medicine supplied }\end{array}$ & $36(35.5 \%)$ & $31(30.1 \%)$ & $21(20.4 \%)$ & $8(7.8 \%)$ & $7(6.8 \%)$ \\
\hline $\begin{array}{l}\text { Counsel buyers about the potential adverse } \\
\text { effects of herbal medicines }\end{array}$ & $25(24.3 \%)$ & $33(32.0 \%)$ & $26(25.2 \%)$ & $13(12.6 \%)$ & $6(5.8 \%)$ \\
\hline $\begin{array}{l}\text { Pharmacists have ever recommended herbal } \\
\text { medicines to buyers }\end{array}$ & $4(3.8 \%)$ & $14(13.6 \%)$ & $27(26.2 \%)$ & $20(19.4 \%)$ & $37(35.9 \%)$ \\
\hline $\begin{array}{l}\text { Pharmacists ever received complaints of } \\
\text { adverse reaction to herbal medicines from the } \\
\text { users }\end{array}$ & $14(13.6 \%)$ & $9(8.7 \%)$ & $21(20.4 \%)$ & $26(25.2 \%)$ & $32(31.0 \%)$ \\
\hline
\end{tabular}

reference materials before supplying herbal medicines, recommending herbal medicines to buyers, and receiving adverse reaction reporting to herbal medicines from the buyers.

Among the 70 pharmacists who had consulted a reference material before supplying herbal medicines, leaflet insert in the herbal medicines pack $(56 \%)$, followed by internet $(20 \%)$, were the two major sources of information (Figure 1). The most frequently sought after information is related to the safety of the herbal medicines, which included drug interactions (85\%), contraindications (75\%) and adverse effects $(70 \%)$.

\section{DISCUSSION}

A wide range of herbal medicines were supplied by the community pharmacies in this study. They included the locally produced (Yoyo cleanser bitters $\AA$, Jobelyn $\AA$, Ciklavit $₫$, herbal tea, Yemkem $\AA$ products, Alomo bitter $\AA$, Oroki herbal mixture $\AA$, and Ajase poki-poki®) and the imported (ginseng, gingko, Aloe vera, GNLD® products, Forever Living products $®$, Tianshi $\AA$ products, Echinacea, St. John's wort and valerian) herbal medicines. While efficacy and safety data for some of the imported herbal medicines are available in the literature to guide their use $\mathrm{e}^{28-31}$, such data are lacking for the

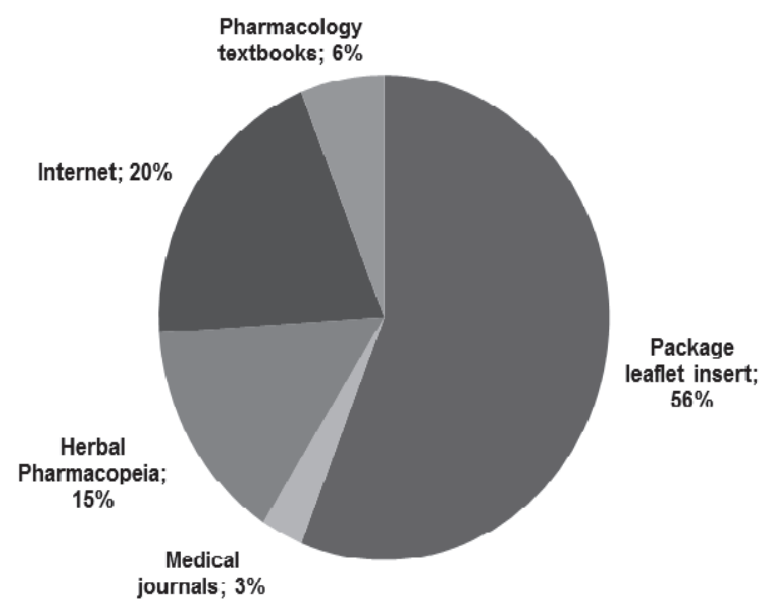

Figure 1. Major sources of herbal medicines information for pharmacists. locally produced herbal medicines. The efficacy and safety of the locally produced herbal medicines supplied by the community pharmacies need to be ascertained by the NAFDAC. Such certification would need to be disseminated to the general populace, through mass media and public enlighten programmes. Although, animal studies were undertaken on the safety of Jobelyn $®$ and Yoyo cleanser bitters $₫$ when used at recommended doses $^{32,33}$, a randomised clinical trial is required in human to corroborate this claim.

Yoyo cleanser bitters $₫$, ginseng and Jobelyn $₫$ were the three most commonly supplied herbal medicines, followed by Ciklavit $\circledast$, ginkgo, herbal tea, and Aloe vera. This was in contrast to the ivy leaves extract and ginseng that were commonly supplied by the community pharmacies in Oman. ${ }^{12}$ Findings from our study also were different from the ginseng, gingko, valerian and St. John's wort that were commonly supplied by the community pharmacies in Saudi Arabia. ${ }^{34}$ Herbal medicines were procured for use by middle-aged adults and the elderly. This trend was similar to the report in Oman. ${ }^{12}$ There is an increasing burden of chronic illnesses such as hypertension, diabetes and HIVIAIDs among the middle-aged adults which defy permanent cure. ${ }^{35}$ Aging is associated with an increased risk of pathological changes that may culminate into cancer, cardiovascular disease, dementia, diabetes, and osteoporosis. ${ }^{36}$ These chronic diseases are currently incurable. The desire of the middle-aged adults and the elderly for a permanent cure of the chronic diseases may have accounted for their increased use of the herbal medicines. Schoenberg et al reported that about $50 \%$ of African Americans, Hispanics, Native Americans, and rural whites with diabetes in the USA were using herbal medicines. ${ }^{37}$ Among this group of patients, long reliance on herbal medicines was sometimes responsible for the delayed diagnosis of their chronic illness.

The pharmacists rated their knowledge of herbal medicines as good $(42 \%)$ and fair $(39 \%)$. This was similar to the findings among the community pharmacists in Kuwait $^{10}$ and Estonia $^{38}$ but contrasting to the findings in the previous studies in Australia $^{13}$, the United Kingdom ${ }^{16}$, the United States $^{17}$ and Singapore ${ }^{18}$ where the pharmacists self-rated their knowledge and ability to appropriately counsel patients on herbal medicines as inadequate. This may reflect cultural differences 
in the perception of herbal medicines by the pharmacists. In contrast to our findings, Adisa and Fakeye $^{9}$ assessed the knowledge of community pharmacists about the commonly supplied herbal medicines in south-western Nigeria and reported that only $26 \%$ of their surveyed participants had a good knowledge of the indications, adverse effects and potential interactions of their supplied herbal medicines. This suggests that, even within a country, knowledge of herbal medicines may vary among community pharmacists in different states or provinces.

Five herbal medicines (Yoyo cleanser bitters $®$, ginseng, St. John's wort, gingko, and valerian) were selected to objectively assess the knowledge of the pharmacists about the safety of herbal medicines (Table 2). Over $80 \%$ of the respondents either strongly agreed or agreed to herb-herb interaction occurring with herbal medicines, and herb-drug interaction occurring when an herbal medicine was used with conventional medicines. These were in agreement with the various studies that have documented adverse interactions of herbal medicines with other herbal products or conventional medicines. ${ }^{29,30}$ Despite the safety concerns for herbal medicines documented in the literature ${ }^{36}$, only about $40 \%$ of the participants in our study always or regularly take the medical or medication history of the potential users. This was lower than the $93.8 \%$ of the community pharmacists in rural Australia who agreed to regularly taking medication history before supplying complementary and alternative medicines including herbal medicines. ${ }^{13}$ Failure to take medication history may put the potential herbal medicine users at risk of an adverse herb-herb or herb-drug interactions.

Despite the numerous data that are available on the indications and adverse effects of the five herbal medicines in this study ${ }^{20-25,38}$, a very low percentage of the participants correctly agreed that Yoyo cleanser bitters ${ }^{\circledR}$ was an immune booster. An equally low percentage correctly disagreed that St. John's wort was a mild to moderate antihypertensive, and correctly agreed to ginkgo preventing dementia. Less than $30 \%$ of the participants correctly agreed to ginseng as a potential blood pressure elevator when used at normal dose. A much lower percentage of the participants correctly agreed to the contraindication of ginseng in diabetes mellitus, correctly disagreed to the increased digoxin blood level by St. John's wort, and correctly agreed to using valerian with caution in a patient on benzodiazepines. In contrast, about $40 \%$ of the participants correctly agreed to the increased risk of bleeding when ginkgo was used concomitantly with warfarin. A similar study among the community pharmacists in Oman has demonstrated a good knowledge of the indications, adverse effects and contraindications of ginseng and St. John's wort among $80 \%$ of the participants. ${ }^{12}$ However, similar to our findings, community pharmacists in Kuwait ${ }^{10}$ and Saudi Arabia $^{34}$ had demonstrated a poor knowledge of the indications, contraindications, interactions and adverse effects of herbal medicines which included ginseng, gingko, and St. John's wort. These findings would suggest that the practical knowledge of our respondents was not in agreement with their selfrated knowledge of the herbal medicines. Such disparity in self-rated knowledge and objectively assessed knowledge of herbal medicine has been reported among the community pharmacists in Kuwait $^{10}$ and Estonia. ${ }^{39}$ As a means of changing the present situation, continuous education that is focused on evidence-based use of local and imported herbal medicines, should be a requisite for renewal of the annual practising licence of community pharmacists in Nigeria.

The participants relied mostly on the leaflet or package insert of the herbal medicines. This is an inappropriate practice as the safety information provided may be inadequate or inaccurate. Raynor et al. evaluated the information provided with herbal medicines (garlic, ginkgo and Asian ginseng, St. John's wort, and Echinacea) available over the counter in the United Kingdom to know if they can enable safe use. ${ }^{40}$ They found that $75 \%$ of the 68 herbal medicines contained none of the important safety information needed by consumers for safe use. Internet and the herbal pharmacopoeias were the other sources of information used by the participants in this study. This was in contrast to the many pharmacists in Oman ${ }^{12}$ and Kuwait ${ }^{10}$ who relied mostly on their undergraduate pharmacognosy lecture notes, followed by textbooks and magazines for herbal medicine information. Our findings also were in contrast to the pharmacists in the United Arab Emirates who mostly sourced herbal medicine information from drug sales representatives. ${ }^{11}$ Fewer participants $(20 \%)$ in the current study than in the Omani study $(30 \%)$ made use of the internet as a source of herbal medicine information. This may have resulted from inadequate access to the internet in Nigeria. Internet and Monthly Index of Medical Specialties ${ }^{13}$; Physicians' Desk Reference for Herbal Medicines and The Review of Natural Products $^{41}$; and internet, package inserts, pamphlets or brochures, and pharmacology textbooks $^{42}$ were the sources of herbal medicine information utilised by the pharmacists in the previous studies. Some of these information resources were less utilised in the current study. The herbal medicine safety information most frequently sought in this study included drug interactions, contraindications and adverse effects. These were similar to the safety information sought by the community pharmacists in Australia ${ }^{13}$, southwestern Nigeria ${ }^{9}$, and the United States. ${ }^{17}$

Self-reporting surveys are characterised by limitations as tools for investigating knowledge, attitude and practice. Participants were self-selected and response bias may have occurred from the participants who displayed greater self-rated knowledge of herbal medicine. Imported herbal medicines, except Yoyo cleanser bitters $₫$, were used to objectively assess the participants' knowledge of the safety profiles of herbal medicines because of their available safety information documented in the literature. The knowledge of the safety profiles may differ if local herbal medicines were used for illustration. The generalisability of the 
results to the entire pharmacists in Lagos State is limited as rural pharmacies were excluded from the survey. This study also was limited to the community pharmacists in Lagos, Nigeria and the results may not represent the entire community pharmacists in the country. A prospective multicentre study that will involve community pharmacists in the six geo-political zones is necessary to ascertain their true knowledge with regards to herbal medicines in Nigeria. A mixed method study incorporating qualitative methods such as focus groups or interviews would have enabled further data to be gathered from the participants.

\section{CONCLUSIONS}

Locally produced and imported herbal medicines are frequently supplied by most of the community pharmacies surveyed in Lagos, Nigeria. Most of the community pharmacists in charge of the pharmacies rated their knowledge of herbal medicines to be fair or good. This was in contrast with the poor knowledge they exhibited about the indications and safety profiles of the herbal medicines. Leaflet insert was the most common source of herbal medicine information utilised by the pharmacists in this study. This information resource is unreliable and may be inadequate or inaccurate in this regard. There is a need for professional development and training of the community pharmacists with regards to the indication, rational use, and safety of herbal medicines.

\section{ACKNOWLEDGEMENT}

The authors are grateful to the Association of Community Pharmacists of Nigeria (ACPN) in Lagos State and the Pharmacists Council of Nigeria (PCN).

\section{CONFLICT OF INTEREST}

None declared.

\section{References}

1. Miller LG, Hume A, Harris IM, Jackson EA, Kanmaz TJ, Cauffield JS, Chin TW, Knell M. White paper on herbal products. American College of Clinical Pharmacy. Pharmacotherapy. 2000;20(7):877-891.

2. Oshikoya KA, Senbanjo IO, Njokanma OF, Soipe A. Use of complementary and alternative medicines for children with chronic health conditions in Lagos, Nigeria. BMC Complement Altern Med. 2008;8:66. doi: 10.1186/1472-6882-8-66

3. World Health Organization. General guidelines for methodologies on research and evaluation of traditional medicine. WHO/EDM/TRM/2000.1. Available from http://whqlibdoc.who.int/hq/2000/WHO_EDM_TRM_2000.1.pdf (Accessed 2013 April 24).

4. Fakeye TO, Tijani A, Adebisi O. A survey of the use of herbs among patients attending secondary-level health care facilities in South-western Nigeria. J Herb Pharmacother. 2007;7(3-4):213-227.

5. Mills E, Cooper C, Seely D, Kanfer I. African herbal medicines in the treatment of HIV: Hypoxis and Sutherlandia. An overview of evidence and pharmacology. Nutr J. 2005;4:19.

6. Bent S, Goldberg H, Padula A, Avins AL. Spontaneous bleeding associated with Ginkgo biloba: a case report and systematic review of the literature. J Gen Intern Med. 2005;20(7):657-661.

7. Skinner CM, Rangasami J. Preoperative use of herbal medicines: a patient survey. Br J Anaesth. 2002;89(5):792-795

8. National Policy on Traditional Medicine and Regulation of Herbal Medicines - Report of a WHO Global Survey. Available from: http://apps.who.int/medicinedocs/pdf/s7916e/s7916e.pdf (Accessed 2013 March 20).

9. Adisa R, Fakeye T. Assessment of the knowledge of community Pharmacists regarding common phytopharmaceuticals Sold in South Western Nigeria. Trop J Pharmaceut Res. 2006;5(2):619-625.

10. Abahussain NA, Abahussain EA, Al-Oumi FM. Pharmacists' attitudes and awareness towards the use and safety of herbs in Kuwait. Pharm Pract (Granada). 2007;5(3):125-129.

11. Fahmy SA, Abdu S, Abuelkhair M. Pharmacists' attitude, perceptions and knowledge towards the use of herbal products in Abu Dhabi, United Arab Emirates. Pharm Pract (Granada). 2010;8(2):109-115.

12. Duraz AY, Khan SA. Knowledge, attitudes and awareness of community pharmacists towards the use of herbal medicines in muscat region. Oman Med J. 2011;26(6):451-453. doi: 10.5001/omj.2011.115

13. Bushett NJ, Dickson-Swift VA, Willis JA, Wood P. Rural Australian community pharmacists' views on complementary and alternative medicine: a pilot study. BMC Complement Altern Med. 2011;11:103. doi: 10.1186/1472-6882-11-103

14. Semple S, Hotham E, Rao D, Martin K, Smith C, Bloustien G. Community pharmacists in Australia: barriers to information provision on complementary and alternative medicines. Pharm World Sci. 2006;28(6):366-373.

15. National Institute of Health. National Centre for Complementary and alternative Medicine (NCCAM). Complementary, Alternative, or Integrative Health: What's in a name? Available from http://nccam.nih.gov/health/whatiscam (Accessed 30 July, 2013).

16. Hutchinson S, Mitchell K, Hansford D, Stewart D. Community pharmacists' views and experiences of counterprescribing in pregnancy. Int J Pharm Pract. 2001;9(1):15-21.

17. Chang ZG, Kennedy DT, Holdford DA, Small RE. Pharmacists' knowledge and attitudes toward herbal medicine. Ann Pharmacother. 2000;34(6):710-715

18. Dolder C, Lacro J, Dolder N, Gregory P. Pharmacists' use of and attitudes and beliefs about alternative medicines. Am J Health Syst Pharm. 2003;60(13):1352-1357.

19. Koh HL, Teo HH, Ng HL. Pharmacists' patterns of use, knowledge and attitudes toward complementary and alternative medicine. J Altern Complement Med. 2003;9(1):51-63. 
20. Brooks P. Undergraduate teaching of complementary medicine. Med J Aust. 2004;181(5):275.

21. Owen D, Lewith G. Teaching integrated care: CAM familiarisation courses. Med J Aust. 2004;181(5):276-278.

22. Tiralongo E, Wallis M. Attitudes and perceptions of Australian pharmacy students towards complementary and alternative medicine- a pilot study. BMC Complement Altern Med. 2008;8:2. doi: 10.1186/1472-6882-8-2

23. Chez R, Jonas W, Crawford C. A survey of medical students' opinions about complementary and alternative medicine. Am J Obstet Gynecol. 2001;185(3):754-757.

24. Pokladnikova J, Lie D. Comparison of attitudes, beliefs and resource seeking behavior for CAM among first- and thirdyear Czech Pharmacy students. Am J Pharm Educ. 2008;72(2):24.

25. Naidu S, Wilkinson J, Simpson M. Attitudes of Australian pharmacists toward complementary and alternative medicines. Ann Pharmacother. 2005;39(9):1456-1461.

26. National Agency for Food Drug Administration and Control. Herbal Medicines and Related Products (Labelling) Regulations 2005. Available at http://www.wipo.int/wipolex/en/text.jsp?file_id=218178 (Accessed 10 November, 2013).

27. Raosoft@ Sample Size Calculator. Available at: http://www.raosoft.com/samplesize.html (Accessed 17 July 2013 ).

28. Sarris J. St. John's wort for the treatment of psychiatric disorders. Psychiatr Clin North Am. 2013;36(1):65-72. doi: 10.1016/j.psc.2013.01.004

29. Jawad M, Schoop R, Suter A, Klein P, Eccles R. Safety and efficacy profile of Echinacea purpurea to prevent common cold episodes: a randomized, double-blind, placebo-controlled trial. Evid Based Complement Alternat Med. 2012;2012:841315.

30. Diamond BJ, Bailey MR. Ginkgo biloba: Indications, Mechanisms, and Safety. Psychiatr Clin North Am. 2013;36(1):7383. doi: 10.1016/j.psc.2012.12.006

31. Choi J, Kim TH, Choi TY, Lee MS. Ginseng for health care: a systematic review of randomized controlled trials in Korean literature. PLoS One. 2013;8(4):e59978. doi: 10.1371/journal.pone.0059978

32. Eniojukan JF, Aina BA. Toxicological profiles of commercial herbal preparation, Jobelyn®. Int J Health Res. 2009;2(4):369-374.

33. Adeyemi OS, Fambegbe M, Daniyan OR, Nwajei I. Yoyo Bitters, a polyherbal formulation influenced some biochemical parameters in Wistar rats. J Basic Clin Physiol Pharmacol. 2012;23(4):135-138. doi: 10.1515/jbcpp-2012-0026

34. Alkharfy KM. Community pharmacists' knowledge, attitudes and practices towards herbal remedies in Riyadh, Saudi Arabia. East Mediterr Health J. 2010;16(9):988-993.

35. National Academy on an Aging Society. Chronic conditions: a challenge for the 21st century. Available from: http://www.agingsociety.org/agingsociety/pdf/chronic.pdf (Accessed 2013 April 24).

36. Wachtel-Galor S, Benzie IFF. Herbal Medicine: An Introduction to Its History, Usage, Regulation, Current Trends, and Research Needs. In: Benzie IFF, Wachtel-Galor S, eds. Herbal Medicine: Biomolecular and Clinical Aspects. 2nd edition. Boca Raton (FL): CRC Press; 2011. Chapter 1. Available from: http://www.ncbi.nlm.nih.gov/books/NBK92773/ (Accessed 25 April 2013).

37. Schoenberg NE, Stoller EP, Kart CS, Perzynski A, Chapleski EE. Complementary and alternative medicine use among a multiethnic sample of older adults with diabetes. J Altern Complement Med. 2004;10(6):1061-1066.

38. Poyares DR, Guilleminault C, Ohayon MM, Tufik S. Can valerian improve the sleep of insomniacs after benzodiazepine withdrawal? Prog Neuropsychopharmacol Biol Psychiatry. 2002;26(3):539-545.

39. Volmer D, Lilja J, Hamilton D, Bell JS, Veski P. Self-reported competence of Estonian community pharmacists in relation to herbal products: findings from a health-system in transition. Phytother Res. 2011;25(3):381-386. doi: 10.1002/ptr.3266

40. Raynor DK, Dickinson R, Knapp P, Long AF, Nicolson DJ. Buyer beware? Does the information provided with herbal products available over the counter enable safe use? BMC Med. 2011;9:94. doi: 10.1186/1741-7015-9-94

41. Nathan JP, Cicero LA, Koumis T, Rosenberg JM, Feifer S, Maltz F. Availability of and attitudes toward resources on alternative medicine products in the community pharmacy setting. J Am Pharm Assoc (2003). 2005;45(6):734-739.

42. Al-Arifi MN. Availability and needs of herbal medicinal information resources at community pharmacy, Riyadh region, Saudi Arabia. Saudi Pharm J. 2013;21(4):351-360. doi: 10.1016/j.jsps.2012.11.004 